\title{
遊園地における遊戯施設の利用行動特性に関する研究 USE OF AMUSEMENT FACILITIES IN AN AMUSEMENT PARK
}

\author{
山口有 次*, 中村良三**, 渡辺仁史*** \\ Yuji YAMAGUCHI, Ryozo NAKAMURA and Hitoshi WATANABE
}

\begin{abstract}
Statistical data and a visitor questionnair at a particular amusement park were analyzed on following 5 aspects.
1. A positive correlation was found between the number of amusement facilities used per visitor and the total number of facilities in the park.

2. Concerning "thrill type" facilities, there was a positive correlation between the rate of use and the total number of people in the park, while there was a strong negative correlation between "marchen type" facilities and park occupancy.

3. When very few attractive facilities were available, a given facility's distance from a park gate had a strong influence on visitors' first choice.

4. A negative correlation was found between the total distance from the park gates and the rate of a given facility being used.

5. It was found that joint use was most likely when the facilities were close to each other. This was found to be especially true for "child type" facilities. People tend to use "thrill type" facilities consecutively regardless of their relative locations.
\end{abstract}

keywords: amusement park, amusement facility, human behavior 遊園地，遊戯施設，人間行動

\section{1. はしめに}

わが国では戦後の経済成長とともに様々なレジャ一空間が登場し 発展しており、人々が生活の豊かさを求める傾向が強まるとともに、 レジャー空間の重要性はますます高まっていると思われる。 遊園地 ${ }^{\text {11 やテーマパーク }}{ }^{\text {住 }}$ は、年間入場者数が100万人を超える ところが数多く存在する。しかし、1983年に東京ディズニーランド がオープンして以来、利用者の要求水準はますます高度になり、競 争相手も増えて、どこも集客にしのぎを削っているのが現状である。 かつては遊戯施設をひとつ造るのに現在ほど費用がかからず、それ でいて数年間は集客効果が持続したが、現在は大型の遊戯施設を導 入しても短期間で飽きられてしまうと言われている。そのような厳 しい環境にあり、遊園地はその魅力を高めていくための高度な空間 計画を必要としている。

しかし、一般的に遊園地の建築計画に関する研究成果は少なく、 レジャ一産業全般においても参考資料は十分には見られず、特に遊 戯施設に関する基礎デー夕はほとんど公開されてない状況にある。

筆者らはレジャー空間の研究グループを組織し、特定のレジャー 空間における人間の行動特性を明らかにすることで、利用者である 人間の目からみた空間のあり方を研究している。遊園地については、

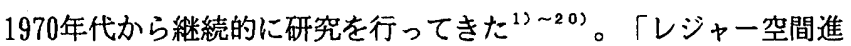

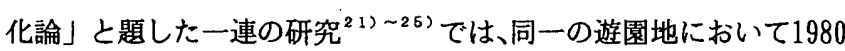
年代から十数年に渡って蓄積してきたデタや調查結果を分析し、 入場者の行動や志向の特性を明らかにすることで空間計画の知見を 得る試みを進めできた。ここでは、その研究成果の一部を紹介する。

\section{2. 研究目的}

本稿は、遊園地の魅力の大きな構成要素 ${ }^{\text {3 }}$ である遊戲施設に視点 を置き、入場者による遊戯施設の利用行動特性を明らかにすること で、遊戯施設の導入計画や動線計画、配置計画などのための基礎資 料やひとつの指針を提供することを目的とする。

\section{3. 研究方法}

本研究は「西武園ゆうえんち」ぎを対象として、以下の方法で行 った。

\section{(1)拄国地の夷䍃テータ}

遊園地が所有する1964年〜95年の年間入場者数、1985年〜95年の 遊戯施設の年間利用者数及び利用率の実績データを入手し分析した。 なお、遊戯施設の利用率は次のように定義される。

遊戲施設の利用率 $\%=$ 年間利用者数 $\div$ 年間入場者数 $\times 100 \quad \cdots(1)$
* 早稲田大学大学院理工学研究科 博士課程·工修

** 早稲田大学大学院理工学研究科 講師・工博

*** 早稲田大学理工学部建築学科 教授. 工博
Graduate School, School of Science and Engineering, Waseda Univ., M. Eng. Lecturer, Graduate School, School of Science and Engineering, Waseda Univ., Dr. Eng. Prof., Dept. of Architecture, School of Science and Engineering, Waseda Univ., Dr. Eng. 


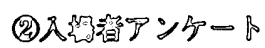

1981年～86年とそれから約10年を経た1995年に同㥞のアンケート を行った。本稿では、最初と 2 番目の利用遊歔施設の選択理由に関す る同一の質問項目を設定した1983年と1995年の調冝結果を比畭・分 析した。また、95年調査では、園内の回遊経路之利用した全ての遊 践施設について調蓇員が聞き取り形式で記録した。なお、入場者の 属性(居住地, 性別, 年齢, 同伴者)別のクロス集計結果には特別な傾向 は見いだせなかった。

\section{表 1 入場者アンケートの調冝概要}

\begin{tabular}{|c|c|}
\hline 年 次 & 调 望 概 \\
\hline 1983年解 & 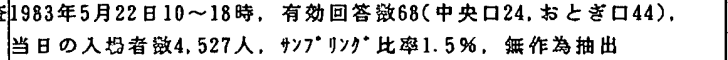 \\
\hline 1995年阙 & 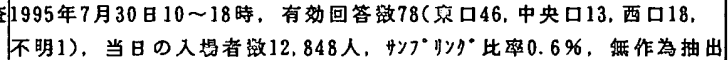 \\
\hline
\end{tabular}
力所のゲートから各遊戲施設の入口まで最短ルートを通った場合の 歩行距離(以下、最短歩行距噰)とその間の直線距離を測定した。ま た、各遊戯施設を利用後に通路を移動して最初に利用機会が与えら れる遊戯施設の種積と数を図面上で求めた(詳細説明は後述する)。

表 2 には、本稿で使用した基劉的なデータの種頻、年次、入手方 法を整理する。図 1 には「西武園ゆうえんち」の平面図を示す。

表 2 本稿で使用した基碐的なデー夕

\begin{tabular}{|c|c|c|}
\hline 绑 & 年 & 入手方法 \\
\hline 年間入堨者政 & 1985年～1995年 & 吏䈍データ \\
\hline 遊线施設の年間利用者政 & 1985年～1995年 & 实落テータ \\
\hline 遊施設泼 & 1985年～1995年 & 宩输データ \\
\hline 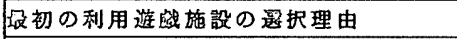 & 1983年、1995年 & 入堨者アンケート \\
\hline 2 番目の利用遊能施設の遥択理由 & 1983年、1995年 & 入堨者アンケート \\
\hline 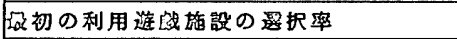 & 1995年 & 入堣省アンケート \\
\hline 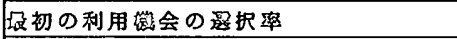 & 1995年 & 入堨者アンケート \\
\hline ゲートから遊施钤までの据短歩行距放 & 1985年～1995年 & 平面図上での测定 \\
\hline 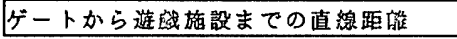 & 1985年～1995年 & 平面図上での测定 \\
\hline
\end{tabular}

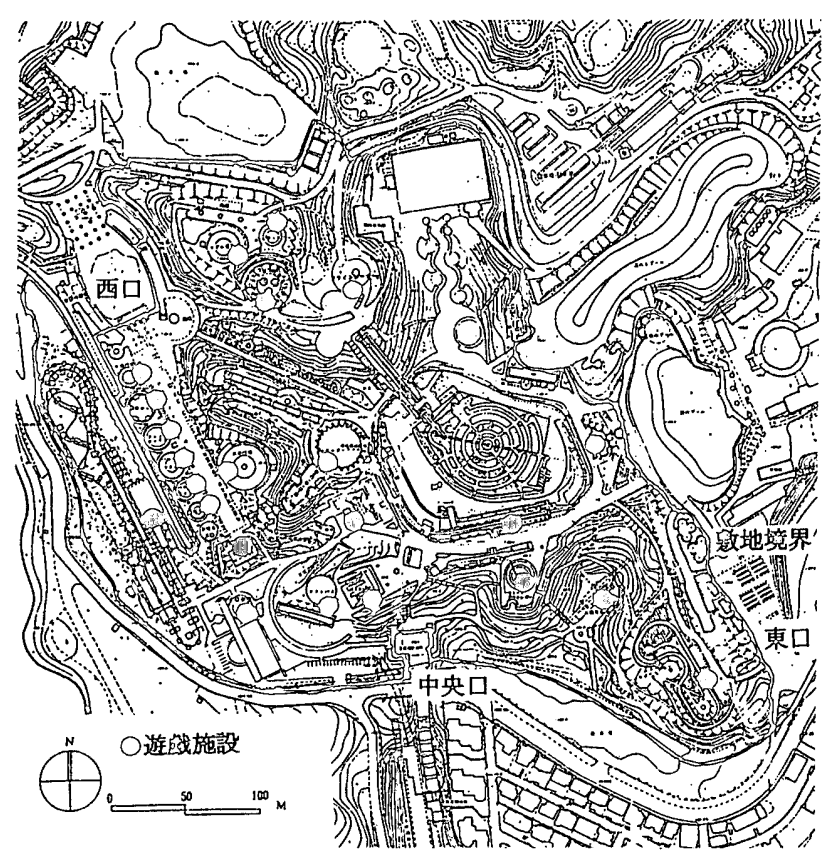

図1「西武園ゆうえんち」の平面図

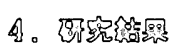

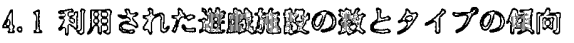

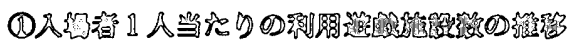

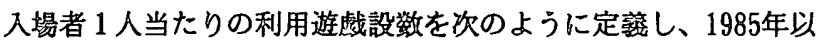
降の実綕データを基に計算した。

\section{入場者 1 人当たりの利用遊践施設数 $=$

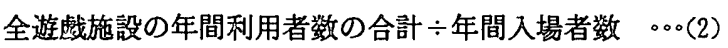

その結果、図 2 に示すように、入場者 1 人当たりの利用遊戯施設 数は、新しい遊戯施設が導入され、遊歔施設数が増加傾向にあった 1985年 90年の間に比輍的大きく伸びたが、遊戯施設数の䒬入がな かったそれ以降は横ばい傾向になっている。そこで、入場者 1 人当 たりの利用遊歔施設数之遊戯施設数の相関分析を行う之、相関係数 $+0.887(\mathrm{t}=5.085$ 、有意水準 $5 \%$ で有意 $)$ という強い相闑關係が認 められる。

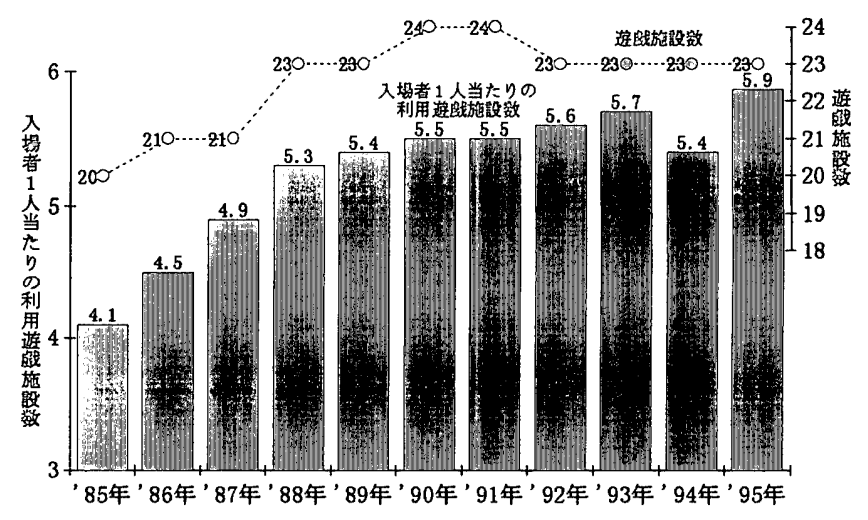

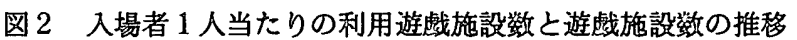

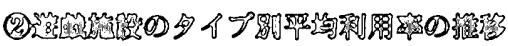

遊戯施設を表 3 に示したような 4 つのタイプに分額し、このタイ プ別に平均利用率を計算した。

\section{遊戯施設のタイプ別平均利用率\%=}

同一タイプの利用率の合計 $\div$ タイプ別遊戯施設数 $\cdots(3)$

表 3 遊戯施設のタイプ別分類

\begin{tabular}{|c|c|c|}
\hline タイプ別 & 待 栍 & 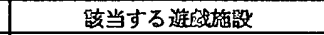 \\
\hline スリル承 & 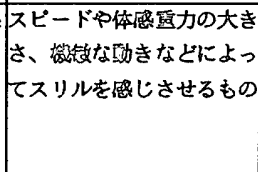 & 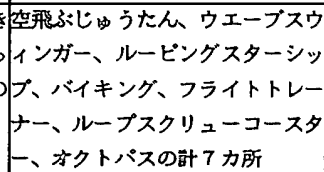 \\
\hline タルヘン柔 & 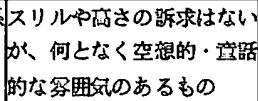 & $\begin{array}{l}\text { 辞ンシシックカー、ウエスリーコーランド、コーヒ } \\
\text { ーカップの草 } 4 \text { カ所 }\end{array}$ \\
\hline 离 亲 係 & 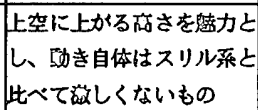 & 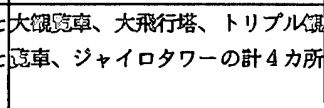 \\
\hline チャイルド & 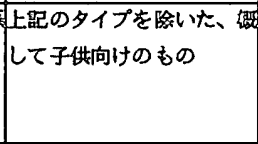 & 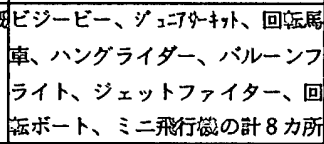 \\
\hline
\end{tabular}

注 : 遊战施設の名称は一般名称ではないが、遊園地ではほぼ 認知されているものが多いため、そのまま使用する。 
その結果、図 3 に示すように、入場者数が増加傾向にあった 1985 年から1988年にかけてスリル系の平均利用率は上昇し、メルヘン系 の平均利用率は下降傾向にあった。逆に、入場者数が減少傾向に転 じた1989年以降は、スリル系の平均利用率は下がり、メルヘン系の 平均利用率は上昇傾向にある。

遊戯施設のタイプ別平均利用率と年間入場者数の回㷌分析を行う と、スリル系の平均利用率と年間入場者数の相関係数は $+0.726(\mathrm{t}$ $=2.793$ 、有意水準 $5 \%$ で有意)であり、正の相関関係が認められる。 メルヘン系の平均利用率之年間入場者数の相関係数は $-0.940(\mathrm{t}=$ -7.290 、有意水準 $5 \%$ で有意)であり、負の強い相関関係が認められ る。高所系、チャイルド系の平均利用率と年間入場者数の相関係数 はそれぞれー0.0564、-0.312であり、相関関係は認められない。

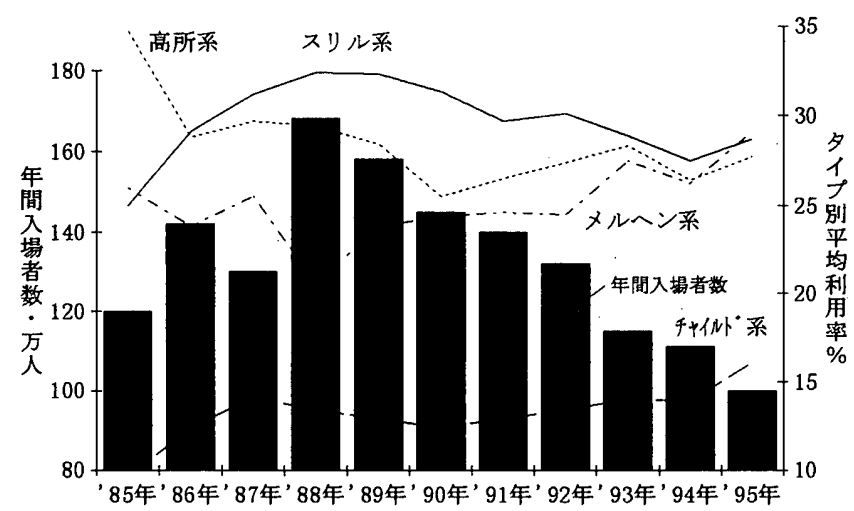

図 3 入場者数之遊戯施設のタイプ別平均利用率の推移

\section{2 物理的な距誰と途践施設の利用の間保}

最初と 2 番目の利用遊戯施設の選択理由について同一の入場者了 ンケートを行った1983年調查（新しい遊戯施設が導入され年間入場 者数が増加傾向にある時期）と1995年調査（遊戯施設の新規導入が 無く年間入場者数が減少傾向にある時期）を比較した。

その結果、図 4 に示すように、最初の利用遊䶢施設の選択理由は、 1983年には「利用を予定していたから」という遊戯施設への目的志 向が強かったが、1995年には「入園ゲートに近かったから」という 物理的な距離の近さの選択理由が強くなっている。

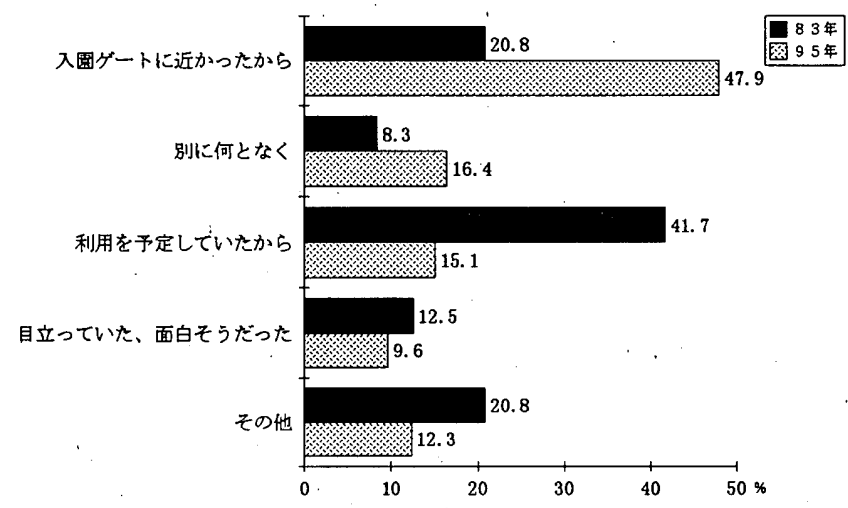

図 4 最初の利用遊戯施設の選択理由
2 番目の利用遊戯施設の選択理由についても、図 5 に示すように、 1983年には「目立っていた、面白そうだった」という遊戯施設の誘 引力が俉いていたが、1995年には「1番目の施設に近かったから」、 「別に何となく」という距離の近さや無目的な選択理由が強くなっ ている。

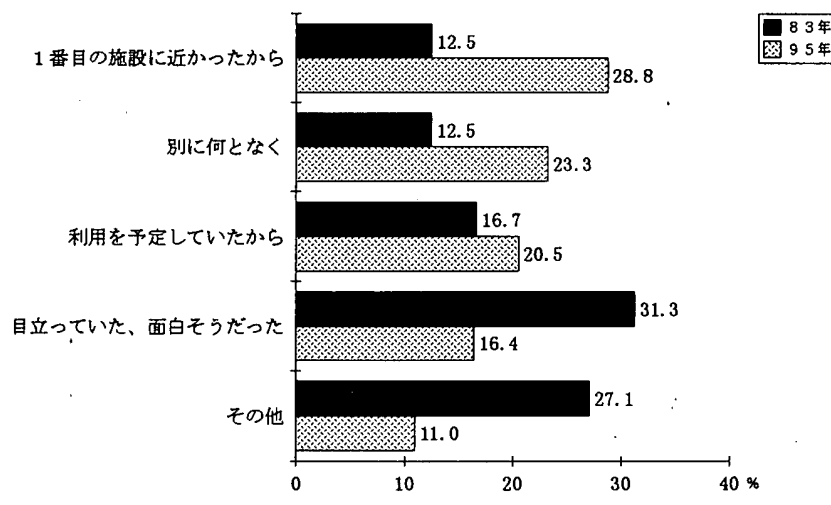

図 52 番目の利用遊戯施設の選択理由

ここで東口から遊戯施設の入口までの最短歩行距離または直線距 離と、1995年調查による最初の利用遊戯施設の選択率の関係を見る と(図 6 )、東口からの距離が200 300 $\mathrm{m}$ 程度までは概ね距離が近い ほど最初の選択率が高くなっている。中央口、西口についてはサン プル数が少ないこともあってか、顕著な傾向は見られなかった。

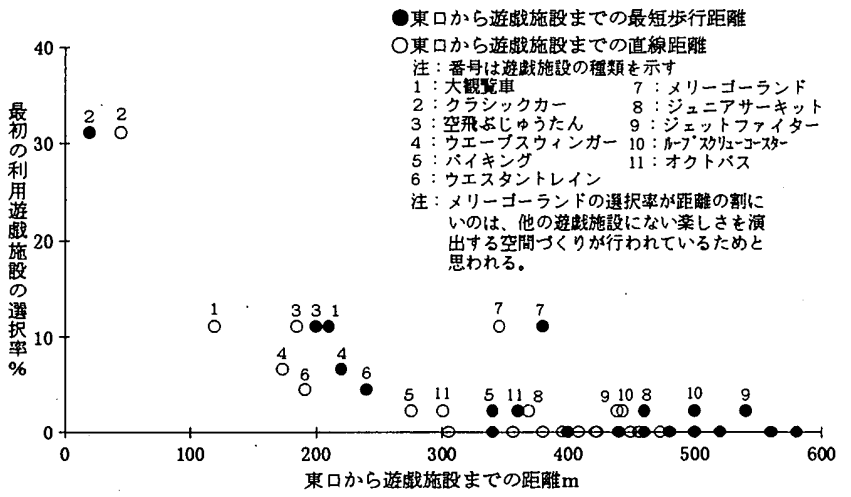

図 6 東口からの距離と最初の選択率の関係(1995年)

次に、図 7 に示す様に、3 力所のゲートからそれぞれの遊戲施設 の入口までの最短歩行距離及び直線距離を合計し、合計最短歩行距 離と合計直線距離を計算した。

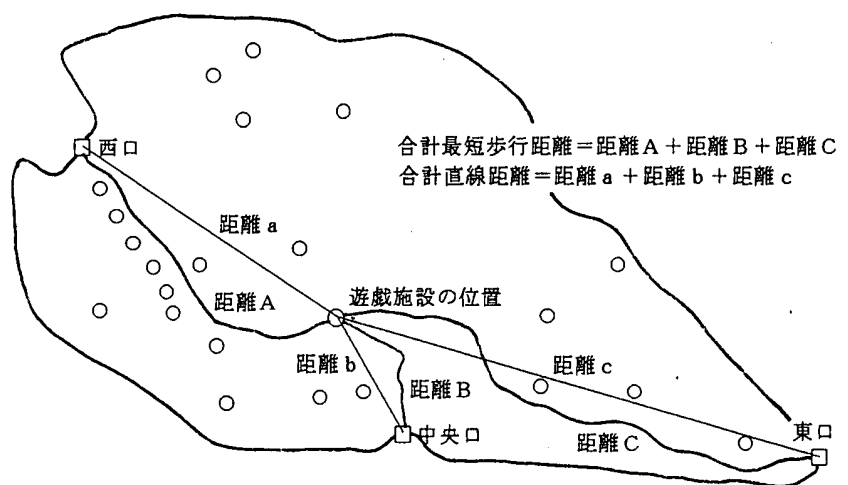

図 7 合計最短歩行距離及び合計直線距離の算出方法 
そして、合計最短歩行距敨又は合計直線距離と1995年時点におけ る遊虥施設の利用率について回帰分析を行った。その結果、合計最 短歩行距離と利用率の相閵係致は $-0.578(\mathrm{t}=-3.085$ 、有意水淖 $5 \%$ で有意）、回㷌式は $Y=89.78-0.07481 X$ 、合計直線距㒕と利 用率の相閵係敋は $-0.804(\mathrm{t}=-5.896$ 、有意水潮 $5 \%$ で有意)、回

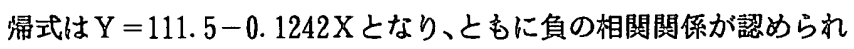
た。

ただし、図 8 に見られるように、ループス䘞ーコースター（図中ではLS」ー スター)は、合計最短歩行距離が比較的大きいにもかかわらず利用率が

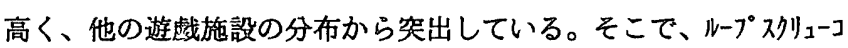

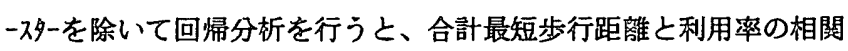
係数はー0.578から-0.806（ $\mathrm{t}=-5.935$ 、有意水準 $5 \%$ で有意）に なり、より強い相開関係が認められる。回帰式はY $=112.6-0.1040$ Xとなる。合計直線距離についてもループスクリューコ一ターを除いて回帰分 析を行う之、相閏係数は -0.804 から $-0.813(t=-6.086$ 、有意水 準 $5 \%$ で有意)と大きな変化はない。回帰式はY $=106.9-0.1185 \mathrm{X}$ となる。

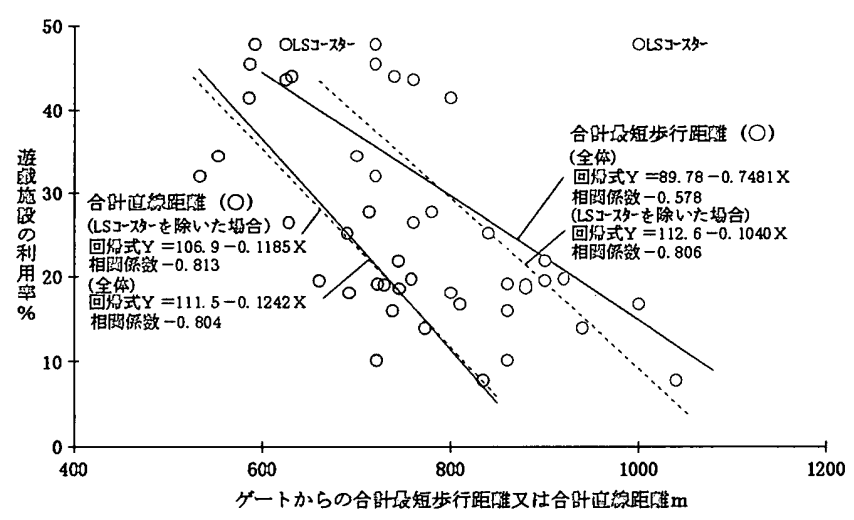

図 8 合計最短歩行距離又は合計直線距離と利用率の䦎係(1995年)

さらに1985年〜95年の間における合計最短歩行距離及び合計直線

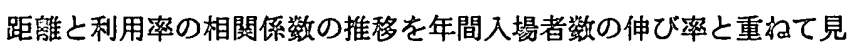
ると(図 9 )、概して年間入場者数の伸び率が上がった時期に相閵係 数が上がり(負の相閏関係が弱まり)、逆に年間入場者政の伸び率が

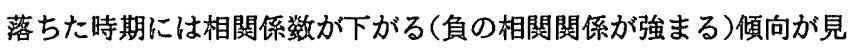
られる。

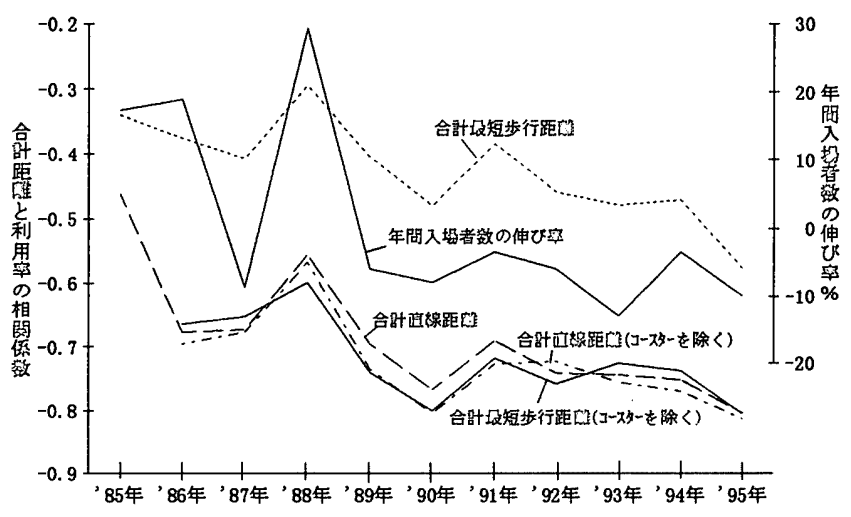

図 9 合計距離と利用率の相䦥係数の推移
図10で合計直線距離の大小と配置の閏係を見ると、西口付近の遊 践施設はゲートの近くであっても合計直線距雄が相榇的に大きくな っている。そのため、ゲートからの合計直湶距離の大きい遊戯施設 に対しては、特別なアクセスや集客のための工夫を施すことが考え られる。計画の初期段階であれば、ゲートからの合計直線距離がで きるだけ均等になるように遊戯施設やゲートを配置することも考え られる。

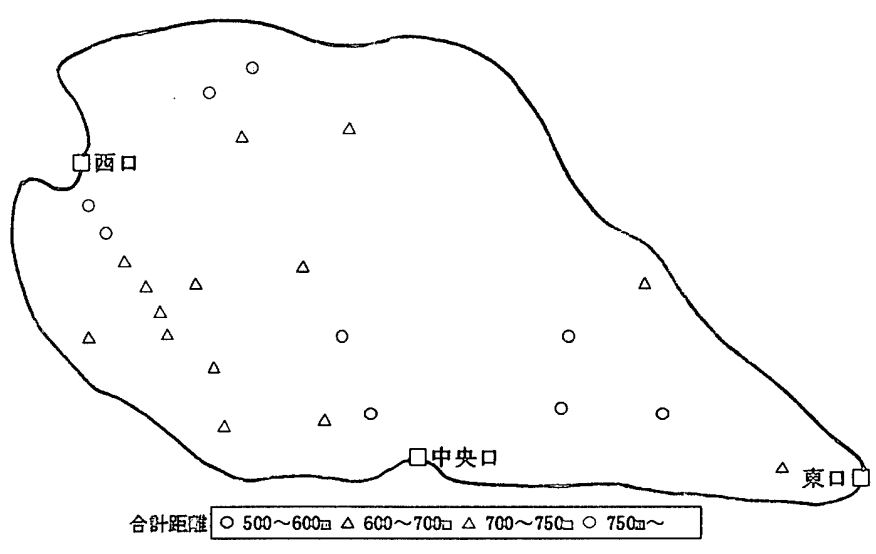

図10 ゲートからの合計直線距離之配置の関係

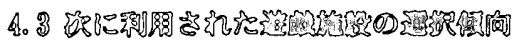

図11のように、当該遊戲施設を利用後に通路を移動し、最初に利 用幾会が与えられる遊虚施設の種頻と新を平面図上で求めた。

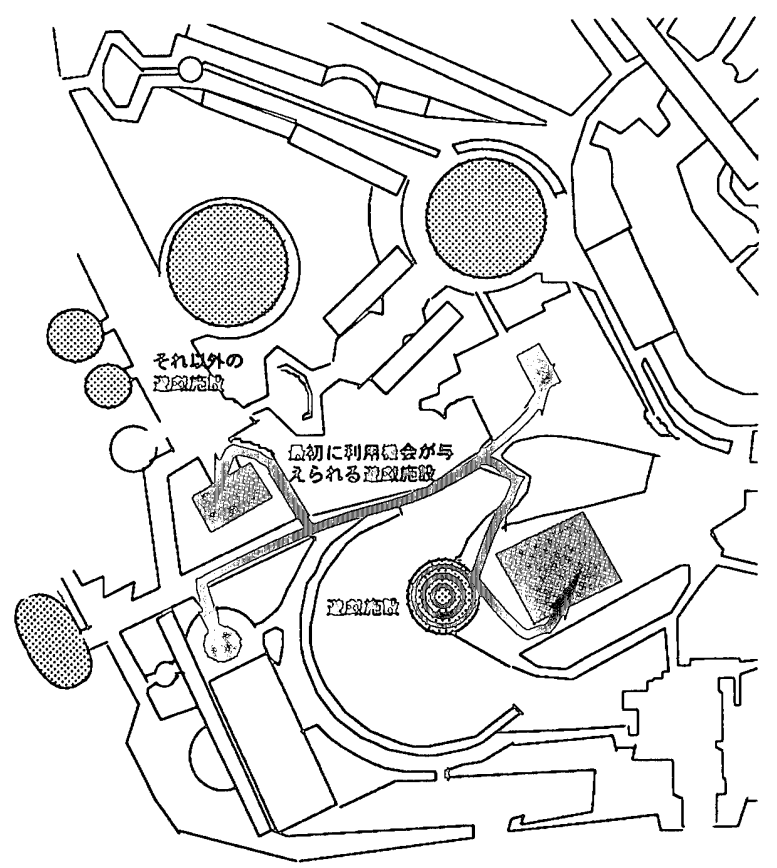

図11 最初に利用幾会が与えられる遊戯施設の捉え方の例

そして、1995年のアンケート結果から、当該遊戲施設の次に利用

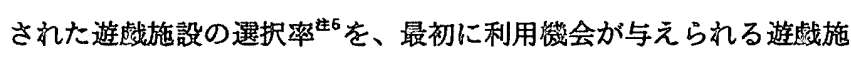
設(最初の利用機会)とそれ以外の別と、それぞれの内敏としての夕 イプ別に分けて集計した(表 4)。次に、当該遊戱施設から見て最初 に利用機会が与えられる遊戱施設の数や、園内にあるタイプ別の遊 
践施設の数がこの選択率に影響を与えていると考えられるため、こ れらの遊戯施設の数から選択率の基準值を計算した（式(4)、表 5$) 。$ 表 4 の実際の選択率と表 5 の基準值の差が、最初に利用機会が与え られた遊戯施設とそのタイプ別に見た選択傾向を表す(表 6 )。

最初に利用機会が与えられる遊戯施設の選択率の基準値\%

$=$ 最初に利用機会が与えられる遊戯施設数 $\div$ 全遊戯施設数 $\times 100$

$=100 \%$ - 最初の利用機会以外の選択率の基準值 $\cdots(4)$

表 4 最初の利用機会及びタイプ別の選択率

\begin{tabular}{|c|c|c|c|c|}
\hline & $\begin{array}{c}\text { スリル系 } \\
\text { の次に }\end{array}$ & \begin{tabular}{|c|} 
メルヘン系 \\
の次に
\end{tabular} & $\begin{array}{l}\text { 高所系 } \\
\text { の次に }\end{array}$ & $\begin{array}{l}\text { チャイルド } \\
\text { 系の次に }\end{array}$ \\
\hline 最初の利用機会を選択 & 44.6 & 33.5 & 34.9 & 60.0 \\
\hline 同、スリル系を選択 & 21.5 & 9. 9 & 13. 2 & 6.8 \\
\hline 同、メルヘン系を選択 & 11.2 & 2.3 & 5.0 & 7.1 \\
\hline 同、高所系を選択 & 8. 2 & 12. 2. & 0.0 & 6.6 \\
\hline 同、チャイルド系を選抗 & 3.7 & 9.2 & 16. 7 & 39.6 \\
\hline 最初の利用機会以外を選択 & 55.4 & 66.5 & 65.1 & 40.0 \\
\hline 同、スリル系を選択 & 28. 5 & 18.3 & 24.9 & 4.5 \\
\hline 同、メルヘン系を選択 & 6.0 & 17.6 & 17.8 & 5.2 \\
\hline 同、高所系を選択 & 15.6 & 15.4 & 12.4 & 8,9 \\
\hline 同、チャイルド系を選択 & 5.3 & 15.1 & 9.9 & 21.4 \\
\hline
\end{tabular}

注 : 単位は\%、「最初の利用機会」とは最初に利用機会が与えられる遊践施 設、横軸のタイプの遊戱施設の次に縱軸の分類の遊戱施設を利用した 選択染、縦軸のタイプ別は最初の利用機会またはそれ以外の内数

表 5 最初の利用機会とタイプ別の選択率の基準値

\begin{tabular}{|c|c|c|c|c|}
\hline & $\begin{array}{c}\text { スリル系 } \\
\text { の次に }\end{array}$ & $\begin{array}{l}\text { メルヘン䋇 } \\
\text { の次に }\end{array}$ & $\begin{array}{l}\text { 高所系 } \\
\text { の次に } \\
\end{array}$ & \begin{tabular}{|l|}
\multirow{2}{*}{ 系のルト } \\
\end{tabular} \\
\hline 最初の利用機会を選択 & 22.1 & 20.5 & 12.5 & 15.3 \\
\hline 同、スリル系を選択 & 9. 1 & 11.4 & 4.5 & 3.4 \\
\hline 同、メルヘン系を選択 & 6.5 & 3.4 & 2.3 & 2. 3 \\
\hline 同、高所系を選択 & 2. 6 & 1.1 & 0.0 & 2.8 \\
\hline 同、チャイルド系を選択 & 3.9 & 4.5 & 5.7 & 6.8 \\
\hline 最初の利用機会以外を選択 & 77.9 & 79.5 & 87.5 & 84.7 \\
\hline 同、スリル系を選択 & 18. 2 & 20.5 & 27.3 & 28.4 \\
\hline 同、メルヘン系を選択 & 11.7 & 10.2 & 15. 9 & 15.9 \\
\hline 同、高所系を選択 & 15.6 & 17.0 0 & 13.6 & 15.3 \\
\hline 同、チャイルド系を選択 & 32.5 & 31.8 & 30.7 & 25.0 \\
\hline
\end{tabular}

注 : 単位は\%、横軸のタイプの遊戯施設の次に最初に利用機会が与えられ る遊戯施設数や園内にあるタイプ別の遊戯施設の数から計算した選択 率の基準值、縦軸の夕イプ別は最初の利用機会またはそれ以外の内数

表 6 最初の利用機会とタイプ別の選択傾向

\begin{tabular}{|c|c|c|c|c|}
\hline & $\begin{array}{l}\text { スリル系 } \\
\text { の次 }\end{array}$ & \begin{tabular}{|c|} 
メルヘン司 \\
の次に
\end{tabular} & $\begin{array}{l}\text { 高所系 } \\
\text { 次に }\end{array}$ & $\begin{array}{l}\text { チャイルト } \\
\text { 系の次に }\end{array}$ \\
\hline 初の利用機会を選択 & 22. 5 & 13.10.10 & 22.44 & $44: 6$ \\
\hline 同、スリル系を選択 & 12. 4 & -1.5 & 8.7 & 3.4 \\
\hline 同、メルヘン系を選択 & 4.7 & -1.1 & 2.7 & 4.8 \\
\hline 同、高所系を選択 & 5.6 & 11.0 & 0.0 & 3.7 \\
\hline 同、チャイルド系を選 & -0.2 & 4.6 & 11.0 & 32.7 7 \\
\hline 最初の利用機会以外を選択 & -22.5 & -13.1 & -22.4 & -44.6 \\
\hline 同、スリル系を選択 & 10.3 & -2.1 & -2.3 & -23.9 \\
\hline 同、メルヘン系を選択 & -5.7 & 7.4 & 1.9 & -10.7 \\
\hline 同、高所系孝 & 0.0 & -1.6 & -1.2 & -6.4 \\
\hline 同、チャイルド系を選択 & -27.1 & -16.7 & -20.7 & -3.6 \\
\hline
\end{tabular}

注 : 单位は\%、「最初の利用機会」とは最初に利用機会が与えられる斿戲施 設、横軸のタイプの遊戯施設の次に䋖軸の分類の遊戯施設が選択され る傾向の強弱を表す、縦軸のタイプ別は最初の利用機会またはそれ以 外の内数、選択率か $20 \%$ 以上かつ基盤値との差が $10 \%$ 以上のケースに 網掛け表示
その結果、当該遊戱施設のタイプにかかわらず、最初に利用機会 が与えられた遊戯施設が利用されやすい傾向が見られる。特にチャ イルド系の遊戯施設については、最初に利用機会が与えられた同じ チャイルド系の遊戯施設が連続的に利用される傾向が強い。一方、 スリル系については、最初の利用機会以外であっても同じスリル系 が利用されやすく、スリル系の遊戯施設はその位置関係にかかわら ず連続的に利用されやすいことが分かる。

\section{5. まとめ}

本稿では、同一の遊園地において蓄積してきた研究データを基に、 いくつかの観点から遊戲施設の利用行動特性を明らかにしてきた。 その要点をまとめると次の通りである。

(1)入場者 1 人当たりの利用遊戯施設数之遊戯施設数には正の相関関 係が認められた。新しい遊虐施設を導入し遊戯施設数を增やしたこ とは、入場者がより多くの遊戯施設を利用する傾向を強めてきた。 (2)遊戲施設をタイプ別に分類すると、スリル系の遊戯施設の平均利 用率は入場者数と正の相関関係に、メルヘン系は負の相関関係にあ る。このことからスリル系の遊戱施設を導入し、このタイプの利用 を促進したことが入場者数の増加と連動してきたことが裏付けられ、 逆に入場者数が停滞している時期におけるメルヘン系の遊戲施設の 人気の底堅さをうかがい知ることもできる。

(3)新しい遊戯施設の導入があった1983年当時には、利用遊戯施設の 選択理由として遊戯施設への目的志向が見られたが、目立った遊戯 施設が少なくなった1995年には物理的な距離の近さが遊戲施設の選 択に大きく影響している。1995年のゲートから遊戯施設までの距離 と最初の利用遊戯施設の選択率の関係では、ゲートからある程度の 距離までは距離が近いほど最初の選択率が高くなっているケースが 見られた。

(4)ゲートからの合計距離（最短歩行距離または合計直線距離）と利 用率には負の相関関係が見られ、ひとつのゲートから近くても各ゲ 一トからの合計距離が遠い場合には、遊戯施設の利用率が相対的に 低くなっている。このことから、特定の遊戯施設やゾーンの利用率 が低くなることを避けるために、ゲートから遊戯施設までの合計距 離を計算し、合訪距離が遠い場合にはアクセスや集客のための工夫 を施したり、出来るだけ合計距離が均等になるように計画すること が考えられる。

(5)1995年調查によると、当該遊戯施設の次には最初に利用機会が与 えられる遊戯施設が利用されやすい。特にチャイルド系の遊戲施設 は最初に利用機会が与えられた同じチャイルド系が連続的に利用さ れている。逆にスリル系については、遊戯施設の配置にかかわらず、 スリル系が連続的に利用されている。

\section{謝辞}

本研究をまとめるにあたり、実績デー夕の提供やアンケートの実 施などにこ協力頂いた「西武園ゆうえんち」の森沢支配人及び関係 者各位に謝意を表します。

\section{付記}

本稿の一部は、日本建築学会大会学術講演梗概集1996年(近畿)に発表したも の 22) 24) に加筆修正したものである。 
泣:

注1)等者らは、遊園地とは料金を払って利用する遊战施設が同一歇地内に 5 力所以上ある空間と定搴している。遊战施設のあるテーマパーク、彭物 图、水族館、微光施設なども遊園地として認識する場合がある。なお、

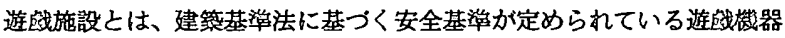
を備えた空間のことを言う。ゲームセンター等にあるアミューズメント マシンやコインライド、またはスポーツ施設は遊战施設に含まれない。

注2)通産省の「特定サービス産業実的調查報告害」では、テーマパークとは、 「遊战施設の有無に関わらず、一定のテーマで全体の璒境を作り、ショ 一やイベントで空間全体を演出したレジャ一施設」と定要している。

注3)入場者アンケート（1981年6月7日10 17時(有効回答效 68 ), 1983年 5 月 22 日 10 18時(有効回答效 68 )，1984年8月5日 10 17時(有効回答效 89 ), 1985 年7月14日11 17時(有効回答数75)，1986年6月7日12 17時(有効回答数 58), 1995年7月30日10～18時(有効回答效78)）による来图目的を見ると、 「主に垂り物(遊战施設)を利用するため」が 4 割から 6 揢を占め一貫し て多い。ただし、95年は86年以前の水洀と比へるとやや落ちており、か わって「久しぶりの休日を皆でのんびり過ごすため、または皆で蛊きに」 という同伴者とのコミュニケーション志向の目的が增加傾向にある。

注4)「西武園ゆうえんち」は埼玉県所沢市の狭山丘陵の自然を生かしてつくら れた遊图地である。オープンは1950年、影地面挽約21万 $\mathrm{m}^{2}$ 。1981年以前 は目立った遊战施設は少なかったか、1982年、1983年にいわゆるビッグ マシンが蓪入された頃から入場者效が増加を始める。1984年には年間入 場者效が100万人を超えている。1985年には規模の小さな18施設が廃辑さ れ、新たに11施設が賉入された大規模りニューアルが行われた。1986年 には現在でも最も人気の高いループスクリューコースターが導入された。 1988年には 2 施設が筞入され、年間入場者数が約168万人之過去垠高とな った。その後は1990年に 1 施設が導入されただけで目立った新遊战施設 の導入はなく、入場者数は減少傾向に䎐じ現在に至っている(図12参照)。

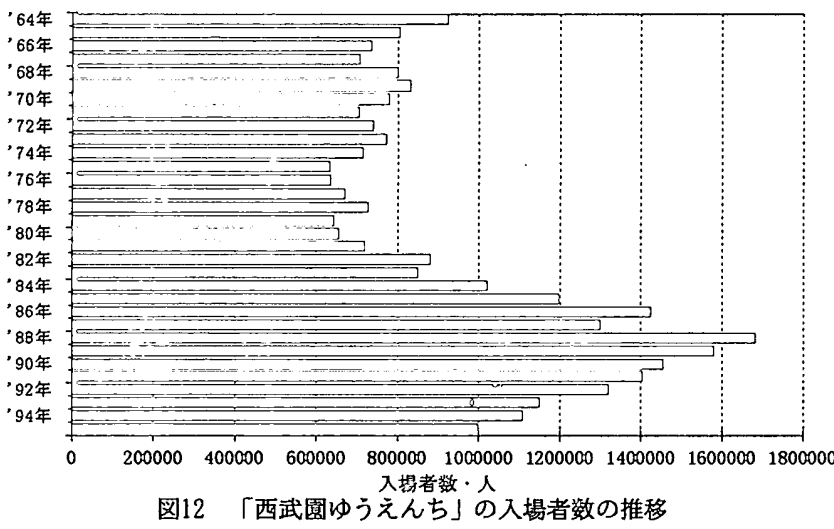

注5)利用された遊晟施設の選択は、簃密にはレストランやトイレの利用など の影留が無視できないか、そ㣗らの行嗔は無作為に発生し、極力近くで 行われていることが観察されたこと、そして本分析が個々の遊戟施設の 選択行锄ではなく平均値により選択傾向を明らかにすることを目的とし ていることから、本稿では園内の回遊を遊戱施設の連続的な利用行晅に 近倾して分析を行った。

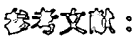

1)中村良三, 内藤, 池原, 大西, 渡辺: 人間一空間系の研究(空間における行彭予 測モテルについて), 日本建築学会諭文報告急, 第185号, pp73-78, 1971.7

2)中村良三, 渡辺, 爂田, 内藤, 浜田, 池原: 人間一空間系の研究(その3情報国に ついて), 日本建築学会論文報告集, 第189号, pp85-90, 1971.11

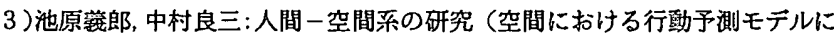
ついて), 早稲田大学理工学研究所報告第 53 号, pp90-101, 1971

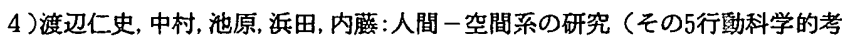
察), 日本建籊学会踰文報告䇣, 第201号, pp59-65, 1972.11

5) 大西健司, 渡辺, 中村, 位寄, 長生, 成做, 水野: 人間-空間系の研究' 82(遊園地 における空間認知亡行動追跡について)，日本建築学会大会学術齐演梗概集， pp1487-1488, 1982. 10

6)大西偉司，渡辺，中村，位㝒，長生，成瀬，水野, 鈴木 : 人間一空間系の研究' 83

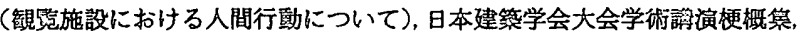
pp1685-1686, 1983.9

7)鈴不大二, 渡辺, 中村, 位㝒, 大西, 長生: 人間一空間系の研究' 83(施設配置検 討時における行動モテルの有効性について), 日本建笻学会大会学術請誼梗 栕急, ppl693-1694, 1983.9

8 )池田浩敬,鈴不大二, 中村良三，渡辺仁史: 遊園地内の遊战施設に打ける利用 客の待ち行勁に関する研究 (待ち行動之施設の棠确効果について), 日本建

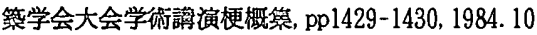

9 )鉿木大二, 中村, 渡边, 池田, 星野：遊園地の施設変更に伴う人間行動の変化 について, 日本貄筑学会大会学術譐演梗概集, pp1431-1432, 1984. 10

10)武田信寞，稲生剛，渡辺仁史，中村良三 : 設計計画理諭(待ち行列からみた施

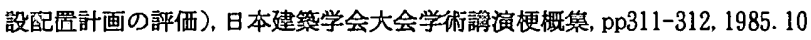

11)金垂州, 鈴木大二, 中村良三, 渡辺仁史:遊園地に於ける人間行厧之施設利用 の研究, 日本建築学会大会学術諏演梗概集, pp387-388, 1985.10

12)金垂州，渡牣仁史，中村良三: 人間一空間系の研究(遊園地の利用者数予湘之 待与空間決定について), 日本建筑学会大会学術語演梗概蘩, pp739-740, 1987. 10

13)永田敬韩，渡辺仁史:遊園地にお打る子供の行動特性と施設配置に関する研

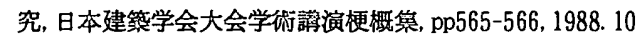

14)金垂州，渡辺仁史:遊圆地の利用者数の予測モデルに関する研究)，日本建筑 学会大会学術塆演梗概急, pp687-688, 1988.10

15)木村幸信: 西武園遊園地' 81, 早稲田大学理工学部建箸学科卒業論文, 1981年 度

16)刧做徹, 山中ゆか里: 西武園遊園地' 83 , 早稲田大学理工学部建築学科卒業論 文, 1983年度

17)小出雄之, 高橋幹一:西武園ゆうえんち’ 85 , 早稲田大学理工学部䞨築学科卒 業論文, 1985年度

18)永田敬蜅: 西武園遊園地' 86 , 早啝田大学理工学部建築学科卒業詥文, 1986年 度

19)内田富也, 広田理, 吉田端: 遊園地の入場者数予測に䦕する研究, 早稲田大学 理工学部建築学科卒業論文, 1987年度

20)岡田邦治、林邦昭、小野寺直樹: 遊園地進化諭, 早稲田大学理工学部建築学 科卒業諭文, 1995年度

21)山口有次，中村良三，渡辺仁史：遊園地の遊战施設の参加性向上に関する実 検 (レジャ一空間進化諭その1), 日本建築学会大会学術請演梗概篹(建筑計 画 I ), pp415-416, 1995.8

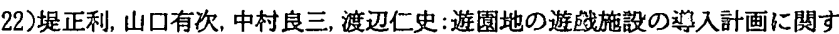
る研究 (レジャ一空間進化諭その3), 日本建築学会大会学術證演浭概集(建 筑計画 I ), pp293-294, 1996. 9

23)山口有次, 堤正利, 中村良三, 渡辺仁史:遊園地の遊战施設の配置計画に関す る研究 (レジャ一空間進化論その4), 日本建築学会大会学術諝演梗概焦(建 築計画 I ), pp295-296, 1996.9

24)林邦昭, 山口有次, 中村良三，渡辺仁史:遊園地の入場者特性の時系列変化に 関する研究 (レジャ一空間進化論その5), 日本建筑学会大会学術㴔演梗概集 (建築計画 I ), pp297-298, 1996.9

25)山口有次: レジャ一空間進化諭(遊園地編), 早稲田大学大学院理工学研究科 修士論文, 1995年度

26)全国レジャーランド名鑑1994、サンケイ新聞データシステム, 1993.9

27)月刊レジャ一库業资料1992年9月号, 総合ユニコム、ppl40-143

28)月刊レジャ一産業资料1993年6月号, 総合ユニコム、pp86-120 